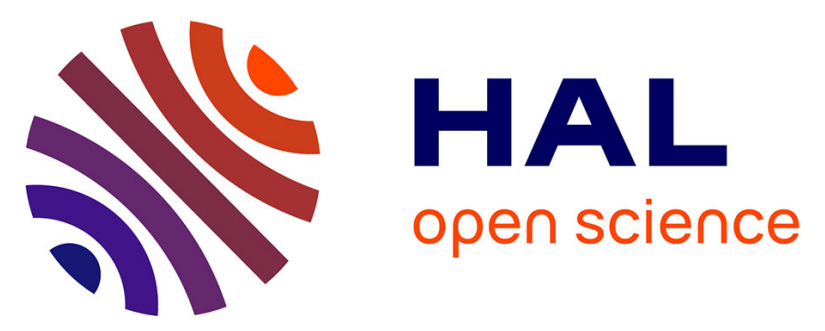

\title{
Introduction to special section: Building complex and realistic geological models from sparse data
}

Guillaume Caumon, Mark Jessell, Eric de Kemp, Balazs Nemeth, Gervais Peron, Ernst Schetselaar

\section{- To cite this version:}

Guillaume Caumon, Mark Jessell, Eric de Kemp, Balazs Nemeth, Gervais Peron, et al.. Introduction to special section: Building complex and realistic geological models from sparse data. Interpretation, 2016, 4 (3), pp.SMi. 10.1190/INT-2016-0614-SPSEINTRO.1 . hal-01356309

\section{HAL Id: hal-01356309 \\ https://hal.univ-lorraine.fr/hal-01356309}

Submitted on 25 Aug 2016

HAL is a multi-disciplinary open access archive for the deposit and dissemination of scientific research documents, whether they are published or not. The documents may come from teaching and research institutions in France or abroad, or from public or private research centers.
L'archive ouverte pluridisciplinaire HAL, est destinée au dépôt et à la diffusion de documents scientifiques de niveau recherche, publiés ou non, émanant des établissements d'enseignement et de recherche français ou étrangers, des laboratoires publics ou privés. 


\section{Introduction to special section: Building complex and realistic geological models from sparse data}

Interpretation 4(3):SMi, August 2016. DOI: 10.1190/INT-2016-0614-SPSEINTRO.1

Guillaume Caumon ${ }^{1}$, Mark Jessell ${ }^{2}$, Eric de Kemp ${ }^{3}$, Balazs Nemeth ${ }^{4}$, Gervais Peron ${ }^{5}$, Ernst Schetselaar ${ }^{3}$

Earth scientists have always created spatial models of the subsurface. Before the dawn of computerbased modeling, earth models were simply drawn by hand on a piece of paper as cross section or plan views, sometimes utilizing the techniques of descriptive geometry. These hand-draw models are quick and easy to create; this is why we are still doing them on white boards, note books and sometimes even on napkins. They communicate ideas very well, but they are subjective and rarely constrained by data in a measurable way. As the number of observations grew with the advancement of data collections technologies, the possibility to use mathematical algorithms to do the modeling became a reality. These processes, first applied in 2D then in 3D, removed some of the subjectivity from the modeling. These processes work very well when the data density is high enough, meaning that models built with different mathematical methods are both realistic and similar one to another.

However, when the data coverage is sparse in the whole or parts of the model space, moving the modeling from the hand-drawn environment into the computer environment creates its own challenges. In these cases the modeling algorithms do not necessarily produce realistic models and the model or parts of it need to be sculpted by hand or guided by some other higher level interpretive knowledge to generate realistic output. In other words, the model creation may become a much more interactive process.

In this special section, this need for expert input is illustrated by Collon et al. who demonstrate how to create a model of a complicated salt body only using outcrop data and conceptual knowledge. They combine automatic implicit methods and more manual explicit modeling approaches to handle thin salt features. Although it is partly automated, this method primarily relies on spatial interpretations, resulting in a relatively tedious process. The authors suggest methods to sample uncertainties and highlight the need for better interpolation rules suited to halokinetic environments.

De Kemp et al. provide an example where more structural observations are integrated into a 3D model from sparse data, and they present a work flow that includes a new implicit modeling algorithm designed to use more of the available information than current implemented software. The authors also discuss the problem of estimating uncertainty of the model and ways of checking the geological reasonableness of it, and finally, they stress the need for work flows suitable to model highly deformed terranes at regional scale.

To address the difficulty of complex data integration in 3D modeling, de la Varga and Wellmann propose a new approach: their idea is to combine "easy" data and interpolation with structural likelihood in a Bayesian framework. This opens the way to confronting data, algorithms, model

\footnotetext{
${ }^{1}$ Nancy School of Geology, Universite de Lorraine Région de Metz, Nancy, France.

${ }^{2}$ Centre for Exploration Targeting, School of Earth and Environment, The University of Western

Australia, Perth, Western Australia, Australia.

${ }_{3}^{3}$ Geological Survey of Canada, Ottawa, Ontario, Canada.

${ }^{4}$ BHP Billiton, Saskatoon, Saskatchewan, Canada.

${ }^{5}$ Mira Geoscience Ltd., Montreal, Quebec, Canada.
} 
parameters and interpretations to reduce uncertainties and could help unravel some new elements during the structural interpretation processes.

To summarize, this thematic set gives an overview of the current strategies and challenges in building models in sparse data contexts. The quest for more objectivity, or, at least for more reproducibility, made a significant leap forward with the advent of implicit structural modeling methods. However, more research is still clearly needed to define suitable geological likelihoods and to integrate geological interpretation concepts directly in the modeling methods and algorithms.

We hope you will enjoy reading these papers and find their content useful and stimulating to solve problems or do more research in the field of geological modeling. 